\title{
CHEMICAL AND NUTRITIONAL EVALUATION OF KERNELS OF BOCAIUVA, Acrocomia aculeata (JACQ.) LODD. ${ }^{1}$
}

\author{
Priscila A. HIANE ${ }^{2}$, Paulo Aparecido BALDASSO ${ }^{3}$, Sérgio MARANGONI ${ }^{3}$, Maria Lígia R. MACEDO ${ }^{4, *}$
}

\section{SUMMARY}

Protein characterization and results of proximate composition and mineral analyses of fruit kernels of bocaiuva, Acrocomia aculeata (Jacq.) Lodd., are reported. The kernels presented high contents of oil (51.7\%), protein (17.6\%) and fiber (15.8\%). The seeds' soluble proteins were isolated according to their solubility. The main separated proteins were globulins (53.5\%) and glutelins (40.0\%). Moreover, the presence of low molecular mass proteases in these two fractions was shown by the SDS-PAGE method. The assays of proteaseinhibitory and hemagglutinating activities showed that bocaiuva's protein fractions were not resistant to trypsin or chymotrypsin activities and that both had low lectin content. The globulin in vitro digestibility assay resembled a casein standard. Neither globulin nor glutelin enzymatic hydrolyses increased significantly $(p<0.05)$ after heat treatment. Threonine and lysine are the most limiting amino acids, respectively from two major protein fractions of the bocaiuva kernel, globulin (47.1\% amino acid score) and glutelin ( $49.5 \%$ amino acid score), in terms of the theoretical profiles for children in the age range of 2 to 5 years recommended by the FAO/ WHO. Bocaiuva kernels are found to be rich in calcium, phosphorus and manganese compared to some fruit nuts such as cashew and coconut.

Keywords: kernel, Acrocomia aculeata, globulin, glutelin, chemical analysis, digestibility.

\section{RESUMO}

AVALIAÇÃO QUÍMICA E NUTRICIONAL DE AMÊNDOAS DA BOCAIÚVA, Acrocomia aculeata (JACQ.) LODD. Caracterização de proteínas e análises da composição centesimal e teores de minerais foram realizados nas amêndoas da bocaiúva, Acrocomia aculeata (Jacq.) Lodd. As amêndoas apresentaram alto teor de lipídio (51,7\%), proteína (17,6\%) e fibra (15,8\%). Proteínas solúveis das sementes foram fracionadas de acordo com a sua solubilidade. As principais proteínas separadas foram as globulinas (53,5\%) e glutelinas (40,0\%), e a presença de proteases de baixo peso molecular nessas duas frações foi revelada por eletroforese em gel de poliacrilamida (SDS-PAGE). Ensaios da atividade inibitória de proteases e da hemaglutinação mostraram que as frações protéicas da bocaiúva não foram resistentes à ação da tripsina e quimotripsina e apresentaram baixo teor de lectina. A digestibilidade in vitro da globulina foi semelhante à da caseína padrão. Hidrólises enzimáticas da globulina e glutelina não aumentaram significativamente $(p<0,05)$, com o aquecimento. Treonina e lisina são os aminoácidos mais limitantes, respectivamente, das duas principais frações de proteínas da amêndoa da bocaiúva, a globulina (escore de aminoácido de $47,1 \%$ ) e glutelina (escore de aminoácido de 49,5\%), relativamente ao padrão teórico para crianças de 2 a 5 anos de idade, recomendado pela FAO/WHO. Amêndoas de bocaiúva mostraram ser ricas em cálcio, fósforo e manganês, em comparação com algumas amêndoas de frutos como caju e coco.

Palavras-chave: amêndoa, Acrocomia aculeata, globulina, glutelina, análise química, digestibilidade.

\section{1 - INTRODUCTION}

In the southwest of Brazil, Bocaiuva is the popular name for the palmtree Acrocomia aculeata (Jacq.) Lodd., Palmae, and its fruit. The species is native to the state of Mato Grosso do Sul, where it is particularly abundant. Other species of the genus occur not only in this state, but also in the southeast of Brazil as well as in Central America. In Brazil, the Acrocomia species are known by a number of common names, which include 'macauba', 'coco catarro', 'macabira', 'mocajuba' and 'macaiba'. Kernels of the bo-

\footnotetext{
${ }^{1}$ Recebido para publicação em 23/11/2005. Aceito para publicação em 6/7/2006 (001643)

2Departamento de Tecnologia de Alimentos e Saúde Pública, (CCBS), Universidade Federal de Mato Grosso do Sul (UFMS),

C. P. 546, CEP 79070-900, Campo Grande (MS)

${ }^{3}$ Departamento de Bioquímica, (IB), Universidade de Campinas,

6121, Campinas (SP)

${ }^{4}$ Laboratório de Purificação de Proteínas e suas Funções Biológicas,

Departamento de Ciências Naturais, (UFMS),

Avenida Olinto Mancini, 1662, Colinos, CEP 79603-021,

Três Lagoas (MS)

E-mail:bioplant@terra.com.br

* A quem a correspondência deve ser enviada
}

caiúva fruit can be eaten raw or as candies such as 'paçoca' (replacing peanuts, the traditional main ingredient) and 'cocada' (replacing coconut) [2].

The cerrado region in Brazil is home to numerous fruit species, some of them with a potential in the market of fruit pulp and nuts, such as the piqui, baru and jatobá-do-cerrado species. Studies have been conducted with the purpose of supplying information that can promote commercial sales of such species and their larger use by the local population as supplementary sources of essential nutrients [14, 21, 27].

Bocaiuva kernels have a high protein content [3, 14], but data concerning their amino acid profile, antinutritional and/or toxic properties are not available.

Food proteins can be classified according to qualitative criteria based on their amino acid profiles and proportions and on their bioavailability and susceptibility to hydrolysis during digestion. Protein nutritional value is related to the quality of its amino acids [11]. Among the sources of plant protein, grains provide protein of high biological value, though deficient in some of the essential amino acids [30]. 
The total protein fraction of seeds is a complex mixture of globulins (40-60\%), albumins (8-20\%), prolamins and glutelins, of which the first two constitute the main components. The proportions, however, differ among species, varieties and/or cultivars [7]. The literature reports that seed protein characterization and evaluation are central aspects in both basic and applied studies in nutrition and biotechnology areas [20,33].

Storage proteins, such as lectins, ureases and proteolytic enzyme inhibitors correspond to $5 \%$ or more of the total protein present in seeds, reserve organs and other plant parts [7].

Some seed proteins such as lectins, proteinase inhibitors and vicilins have been extensively studied in Leguminosae (beans, soybeans, peanuts) and cereals (wheat, rye, barley). In plants, these proteins are associated to the defense mechanism and have bactericide, fungicide and insecticide properties [10, 19]. In human and animal diets, they are considered to play an antinutritional and/or toxic role, as they can inhibit growth in experimental animals, as well as decrease protein digestibility and cause pancreatic hypertrophy and hyperplasia [18]. The evaluation of protein fractions in foodstuffs can thus have a direct influence on the acceptability and use of food items as it can reveal characteristics that are related to their quality and safety in the context of Public Health and Nutrition [30].

In the present investigation, protein fractions of bocaiuva kernels were evaluated focusing on their nutritional potential by carrying out chemical analyses for proximal composition, amino acid composition, mineral content, activity as enzyme inhibitors and protein isolation and digestibility.

\section{2 - MATERIAL AND METHODS}

\section{1 - Material}

Mature fruits of the bocaiuva, A. aculeata (Jacq.) Lodd., were collected from the campus at the Universidade Federal de Mato Grosso do Sul (UFMS) in Campo Grande, MS, Brazil from December, 2002 to March, 2004 - except for February to April, which are months that are not part of the harvesting season.

The kernels were removed from the seeds, triturated in a Turratec crusher and sifted to 60-mesh size particles, thus yielding the whole base flour. Part of the flour was defatted with petroleum ether p.a. (b.p. $30-60{ }^{\circ} \mathrm{C}$ ) for protein evaluation (isolation, composition and digestibility).

\section{2 - Methods}

\subsection{1 - Proximate analysis of kernels}

For the proximate analysis, the moisture content was determined by drying samples in a stove at $105{ }^{\circ} \mathrm{C}$ according to the method described in the analytical norms of INSTITUTO ADOLFO LUTZ [16]. The total protein was determined by the total nitrogen content (\%) according to the Kjeldahl method described in AOAC [4] adopting a nitrogen conversion factor of 5.75, and also by using a procedure developed by BRADFORD [6], which uses bovine serum albumin (BSA) as the protein standard. Crude lipid (ether extract) and ash (fixed mineral residue) contents were analyzed according to AOAC [4]. Furthermore, dietary fiber was determined by the neutral detergent fiber method [32]. The total sugar content was determined by the reduction method according to the procedure described in the analytical norms of INSTITUTO ADOLFO LUTZ [16].

\subsection{2 - Isolation of meal proteins}

The seed protein fractions used in the present study - namely albumins, globulins, prolamins, glutelins and residue - were prepared according to a sequential extraction procedure with $\mathrm{NaCl}$, ethanol and $\mathrm{NaOH}$ [19]. Fifteengram portions of kernel flour were extracted with $150 \mathrm{~mL}$ of $4 \% \mathrm{NaCl}$ for $1 \mathrm{~h}$. The slurry was centrifuged at $17000 \times \mathrm{g}$ for $30 \mathrm{~min}$ at $4{ }^{\circ} \mathrm{C}$ and the supernatant was then dialyzed against distilled water to separate the albumin and globulin. The residue of the salt extraction was suspended in $70 \%$ ethanol for $1 \mathrm{~h}$ and again centrifuged as described above to obtain prolamins. An alcohol-insoluble pellet was suspended in $0.1 \mathrm{M} \mathrm{NaOH}$ and extracted for $1 \mathrm{~h}$. Glutelins were then obtained by centrifugation as described above. All the fractions plus the final insoluble residue were recovered by dialysis and freeze-drying.

\subsection{3 - Molecular mass estimation}

SDS-PAGE was performed according to LAEMMLI [ 17]. The molar mass of the proteins was calculated by comparing them with protein molar mass markers (phosphorylase b, $94 \mathrm{kDa}$; bovine serum albumin, $67 \mathrm{kDa}$; egg albumin, $43 \mathrm{kDa}$; carbonic anhydrase, $30 \mathrm{kDa}$; trypsin inhibitor, $20.1 \mathrm{kDa}$; lysozyme, $14.4 \mathrm{kDa}$ ).

\subsection{4 - Amino acid composition}

An amino acid analysis was performed on a PicoTag amino acid analyzer (Waters) as described by HENRIKSON \& MEREDITH [12]. One nanomole of protein fraction was hydrolyzed in $6 \mathrm{M} \mathrm{HCl} / 1 \%$ phenol at $106{ }^{\circ} \mathrm{C}$ for $24 \mathrm{~h}$. The hydrolysate reacted with $20 \mu \mathrm{L}$ of fresh derivatization solution (methanol triethylamine: water: phenylisothiocyanate, $7: 1: 1: 1, \mathrm{v} / \mathrm{v}$ ) for $1 \mathrm{~h}$ at room temperature. After pre-column derivatization, phenylisothiocyanate (PTC) amino acids were identified on a reverse-phase HPLC-column by comparing their retention times to those of standard PTC amino acids (Pierce). Cysteine residues were quantified as a cysteic acid. Based on amino acid composition, the essential amino acid score according to HENLEY \& KUSTER [11] was estimated, where:

Score $(\%)=$

the most limiting amino acid of the test protein

the same most limiting amino acid in the reference pattern (1)

$\times 100$ 


\subsection{5 - Inhibitory activity assay}

Bovine pancreatic trypsin and bovine pancreatic chymotrypsin were used for the enzymatic assays. Trypsinlike activities were assayed using $\mathrm{N} \alpha$-benzoyl-DL-arginine $p$-nitroanilide (BApNA) as a substrate. Chymotrypsin-like activities were assayed using N-benzoyl-L-tyrosine $p$-nitroalide (BTpNA) as a substrate [20]. In a standard assay, a reaction mixture contained $50 \mu \mathrm{L}$ of each enzyme extract, a reaction buffer (0.1-M Tris- $\mathrm{HCl}$ buffer, $\mathrm{pH} 8.0$ ) and $50 \mu \mathrm{L}$ of $1-\mathrm{mM}$ substrate to a final volume of $500 \mu \mathrm{L}$. The reaction was stopped by adding $200 \mu \mathrm{L}$ of $30 \%$ acetic acid. The release of $p$-nitroaniline groups was measured spectrophotometrically at $410 \mathrm{~nm}$.

The protease inhibitor was assayed by preincubating $50 \mu \mathrm{L}$ of each fraction at concentrations ranging from 25 to $200 \mu \mathrm{g}$ with $50 \mu \mathrm{L}$ of protease and $350 \mu \mathrm{L}$ of the reaction buffer at $37{ }^{\circ} \mathrm{C}$ for $15 \mathrm{~min}$. The reaction was started by adding the substrate and was done as described above. The remaining activity was expressed as the percentage of the enzymatic activity in the absence of the inhibitor.

\subsection{6 - Hemagglutination assay}

Hemagglutination assays were done on microtiter U-plates using serial dilutions with $50-\mu \mathrm{L}$ volumes of $0.15-\mathrm{M} \mathrm{NaCl}$. A $50-\mu \mathrm{L}$ volume of a $2 \%$ suspension of type A human erythrocytes was added and after $1 \mathrm{~h}$ at room temperature, the results were read. The hemagglutination titer, defined as the reciprocal of the highest dilution showing hemagglutination, was defined as one hemagglutination unit [10].

\subsection{7 - In vitro protein digestibility}

This assay was carried out according to OSHODI et al. [24]. A $31.25 \mathrm{mg}$ sample of protein (either globulin or glutelin) was dissolved in $5 \mathrm{~mL}$ of distilled water and the $\mathrm{pH}$ was adjusted to 8.0 with $0.1 \mathrm{~N} \mathrm{HCl}$ and/or $0.1 \mathrm{~N} \mathrm{NaOH}$ while stirring at $37^{\circ} \mathrm{C}$. A multienzyme solution consisting of $1.6 \mathrm{mg}$ of trypsin, $3.1 \mathrm{mg}$ of chymotrypsin and $1.3 \mathrm{mg}$ of peptidase per $\mathrm{mL}$ was maintained in an ice bath and adjusted to $\mathrm{pH} 8.0$ as described above. A $0.5 \mathrm{~mL}$ aliquot of the multienzyme solution was added to the protein sample solution and was constantly stirred at $37^{\circ} \mathrm{C}$. The $\mathrm{pH}$ of the solution was recorded $10 \mathrm{~min}$ after adding the enzyme solution. The in vitro digestibility was calculated using the HSU et al. equation [15].

$Y=210.46-18.1 X$

where $Y$ is the in vitro digestibility (\%) and $X$ is the $\mathrm{pH}$ of the sample suspension after 10 min digestion with the multienzyme solution. A casein standard from Sigma was also analyzed as a reference for in vitro digestibility.

The relative molecular masses of the digestion products were estimated by SDS-PAGE using protein markers of a known molecular mass.

\subsection{8 - Mineral analysis}

The analysis was carried out according to the methodology described by SALINAS \& GARCIA [28] involving organic digestion with acids. An atomic absorption spectrophotometer with acetylene (Perkin-Elmer 2380) was used to determine calcium, magnesium, iron, manganese, zinc and copper contents with wavelengths and slits of, respectively, $422.7 \mathrm{~nm}$ and $0.7 \mathrm{~mm} ; 285.2 \mathrm{~nm}$ and $0.7 \mathrm{~mm} ; 248.3 \mathrm{~nm}$ and $0.2 \mathrm{~mm} ; 279.5 \mathrm{~nm}$ and $0.2 \mathrm{~mm} ; 213.9 \mathrm{~nm}$ and $0.7 \mathrm{~mm}$; and $324.7 \mathrm{~nm}$ and $0.7 \mathrm{~mm}$. A flame photometer (Micronal B262) was used to determine the sodium (589 nm) and potassium $(768 \mathrm{~nm})$. A visible light spectrophotometer (Femto 482 ) was used for phosphorus (420 nm).

\subsection{9 - Statistical analysis}

The results were expressed as means \pm standard deviation, when applicable. Data underwent an analysis of variance (ANOVA) (general linear models, or GLM, procedure). Whenever a difference was found between treatments, the Student's $t$-test was used to determine the level of significance $(p<0.05)[26]$.

\section{3 - RESULTS}

\section{1 - Proximate analysis}

Table 1 shows the results of the proximate analysis of kernels. The kernels were found to have high protein content (17.6\%), as compared to some cerrado fruit kernels and other palmtree species [3, 21]. Furthermore, they showed quite high lipid content (51.7\%). Such protein and lipid values are significant, as they constitute, respectively, $12.5 \%$ and $82.9 \%$ of the total energy, showing that bocaiuva kernels are a good energy source. The kernels also have high fiber content (15.84\%).

TABLE 1 - Proximate composition of kernels of bocaiuva, Acrocomia aculeata (Jacq.) Lodd., expressed as $\mathrm{g} / 100 \mathrm{~g}$ of integral matter.

\begin{tabular}{lc}
\hline \multicolumn{1}{c}{ Component } & Results $^{*}$ \\
\hline Moisture & $6.50 \pm 0.06$ \\
Ash & $1.99 \pm 0.02$ \\
Crude lipid (ether extract) & $51.71 \pm 2.90$ \\
Reducing sugars, in glucose & $1.55 \pm 0.12$ \\
Nonreducing sugars, in sucrose & $\mathrm{ND}$ \\
Nonreducing sugars, in starch & $4.84 \pm 0.25$ \\
Protein (Kjeldahl-N** $\times$ 5.75) & $17.57 \pm 0.57$ \\
Total dietary fiber & $17.23 \pm 0.49$ \\
Total calorie content $(\mathrm{kcal} / 100 \mathrm{~g})$ & $561.23 \pm 26.04$ \\
\hline
\end{tabular}

$\mathrm{ND}=$ not detected; ${ }^{*}$ Mean values \pm standard deviation of two triplicate determinations and ${ }^{* *}$ Nitrogen by the Kjeldahl method.

\section{2 - Isolation of kernel proteins}

The protein content of the defatted kernel flour (as determined by Bradford's method) was $32.5 \%$. The soluble proteins were fractionated according to their solubility. Most 
of these proteins were present in the globulin (salt soluble) (53.5\%) and glutelin (alkali soluble) $(40.0 \%)$ fractions (Table 2). The extraction with organic solvent showed that the seeds were almost devoid of prolamins (1.1\%).

TABLE 2 - Soluble protein fractionsin kernels of bocaiuva, Acrocomia aculeata (Jacq.) Lodd.

\begin{tabular}{cc}
\hline Protein fraction & Protein $(\%)^{*}$ \\
\hline Globulin & 53.5 \\
Glutelin & 40.0 \\
Albumin & 5.4 \\
Prolamin & 1.1 \\
\hline
\end{tabular}

\section{3 - Molecular mass estimation}

As revealed by SDS-PAGE (Figure 1), the globulin fraction showed three protein bands, one of them above $100 \mathrm{kDa}$, one of $66 \mathrm{kDa}$ and one of $60 \mathrm{kDa}$, all of which were absent from the glutelin fraction. However, other protein bands with the same profile were seen in both protein fractions. Lanes 3,4 and 5 in Figure 1 also show that the globulin and glutelin fractions were digested by multienzymes. The glutelin fraction was less susceptible to digestion by enzymes than its globulin counterpart. Both fractions showed a protein band ( $14 \mathrm{kDa}$ ) that was not digested by enzyme complexes. This polypeptide was particularly resistant to attack by digestive enzymes. Protein bands above $22 \mathrm{kDa}$ were more easily digested.

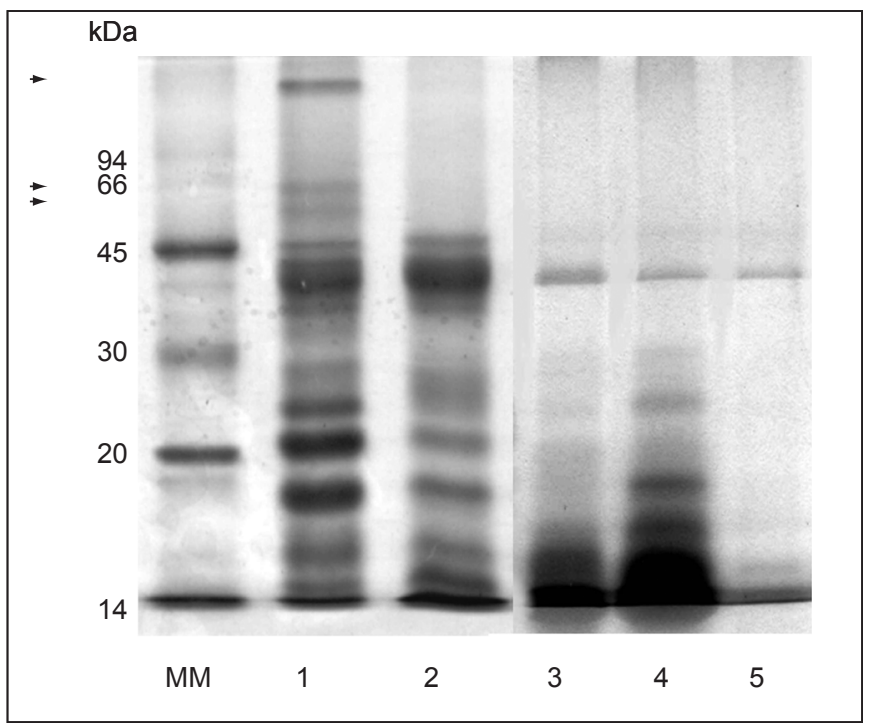

FIGURE 1 - SDS-PAGE of globulins and glutelins in kernels of bocaiúva, Acrocomia aculeata (Jacq.) Lodd. Lane MM, molecular mass markers; lane 1, globulin; lane 2, glutelin; lane 3, globulin digested with multienzyme solution; lane 4 , glutelin digested with multienzyme solution; and lane 5, multienzyme solution.

\section{4 - Amino acid composition}

The amino acid profiles of the kernel protein fractions are shown in Table 3 beyond the proposed FAO/WHO [8] amino acid requirement pattern for the pre-school age group
(2-5 year old). Results show that bocaiúva protein fractions are potentially good sources of some essential amino acids, as they are rich in methionine + cisteyne, valine and leucine. According to the FAO requirement standard, globulin, prolamin and albumin fractions of the bocaiúva kernel showed threonine as first limiting amino acid, revealing that it was also deficient in histidine, phenylalanine + tyrosine and lysine contents; and regarding the glutelin fraction, lysine was found to be the most limiting amino acid, followed by histidine and phenylalanine + tyrosine.

TABLE 3 - Amino acid composition of kernels of bocaiuva protein fractions, Acrocomia aculeata (Jacq.) Lodd., expressed as $\mathrm{g} / 100 \mathrm{~g}$ protein.

\begin{tabular}{|c|c|c|c|c|c|}
\hline \multirow[t]{2}{*}{ Amino acid } & \multicolumn{2}{|c|}{ Bocaiuva } & \multicolumn{2}{|c|}{ Proteins } & \multirow[t]{2}{*}{ FAO $^{1}$} \\
\hline & Globulin & Glutelin & Prolamin & Albumin & \\
\hline Aspartic acid & 6.25 & 8.70 & 6.87 & 7.27 & - \\
\hline Glutamic acid & 20.43 & 15.65 & 22.85 & 21.83 & - \\
\hline Serine & 5.24 & 6.09 & 4.27 & 4.23 & - \\
\hline Glycine & 8.55 & 8.66 & 10.32 & 8.68 & - \\
\hline Histidine & 1.34 & 1.57 & 0.87 & 1.14 & 1.9 \\
\hline Arginine & 13.37 & 11.74 & 10.09 & 11.45 & - \\
\hline Threonine & 1.60 & 3.63 & 1.40 & 1.69 & 3.4 \\
\hline Alanine & 6.63 & 6.95 & 8.53 & 6.82 & - \\
\hline Proline & 4.71 & 4.60 & 6.26 & 6.04 & - \\
\hline Valine & 6.24 & 6.87 & 5.13 & 5.70 & 3.5 \\
\hline $\begin{array}{l}\text { Methionine + } \\
\text { Cisteyne }\end{array}$ & 3.15 & 3.87 & 3.63 & 4.20 & 2.5 \\
\hline Isoleucine & 3.38 & 4.13 & 2.56 & 2.91 & 2.8 \\
\hline Leucine & 7.19 & 6.92 & 6.80 & 7.09 & 6.6 \\
\hline $\begin{array}{l}\text { Phenylalanine + } \\
\text { Tyrosine }\end{array}$ & 6.21 & 5.72 & 5.21 & 5.08 & 6.3 \\
\hline Lysine & 5.72 & 2.87 & 5.19 & 5.75 & 5.8 \\
\hline $\begin{array}{l}\text { Essential amino } \\
\text { acid score (\%) }\end{array}$ & 47.1 & 49.5 & 41.2 & 49.7 & - \\
\hline $\begin{array}{l}\text { Limiting amino } \\
\text { acid }\end{array}$ & Thr & Lys & Thr & Thr & - \\
\hline
\end{tabular}

Note: Tryptophan was not determined. ${ }^{1} \mathrm{FAO} / \mathrm{WHO}$ requirement standard (1991) for the pre-school age group (2-5 year olds). Values found for bocaiúva kernel aminoacids are the average of two repetitions.

\section{5 - Protease-inhibitory and hemagglutinating activities}

The protease-inhibitory activity of the kernel proteins is summarized in Table 4. Neither globulins nor glutelins showed trypsin or chymotrypsin inhibitory activities. The kernel extracts agglutinated human erythrocytes at very high titers.

TABLE 4 - Protease-inhibitory and hemagglutinating activity of kernel proteins of bocaiuva, Acrocomia aculeata (Jacq.) Lodd.

\begin{tabular}{lccc}
\hline \multicolumn{1}{c}{ Proteins } & $\begin{array}{c}\text { Hemagglutinating } \\
\text { activity (titer)* }\end{array}$ & \multicolumn{2}{c}{ Proteases } \\
\cline { 3 - 4 } & 2 & Trypsin & Chymotrypsin \\
\hline Globulin & 3 & ND & ND \\
Glutelin & & ND & ND \\
\hline
\end{tabular}

*Titer is defined as the reciprocal of the endpoint dilution that caused detectable agglutination of erythrocytes. The amount of proteins used in the assays was $500 \mu \mathrm{g} / \mathrm{mL}$; and ND: not detected. 


\section{6 - In vitro protein digestibility}

The digestion of native and heated globulins and glutelins by a multienzyme solution consisting of trypsin, chymotrypsin and peptidase was compared to that of a casein standard (Figure 2). The mean values for in vitro protein digestibility of kernel globulins, glutelins and caseins (for boiled and non-boiled samples) were respectively $78 \%$ and $82 \%$ for globulins, $69 \%$ and $72 \%$ for glutelins and $80 \%$ and $84 \%$ for caseins. Heat treatment did not significantly increase the enzymatic hydrolysis of the globulins and glutelins investigated. In vitro digestibility of native and heated kernel globulins was similar to that of casein. Under boiling and non-boiling conditions, the casein standard and the bocaiuva kernel globulins were more easily digested than the glutelins, whose proteases were investigated.

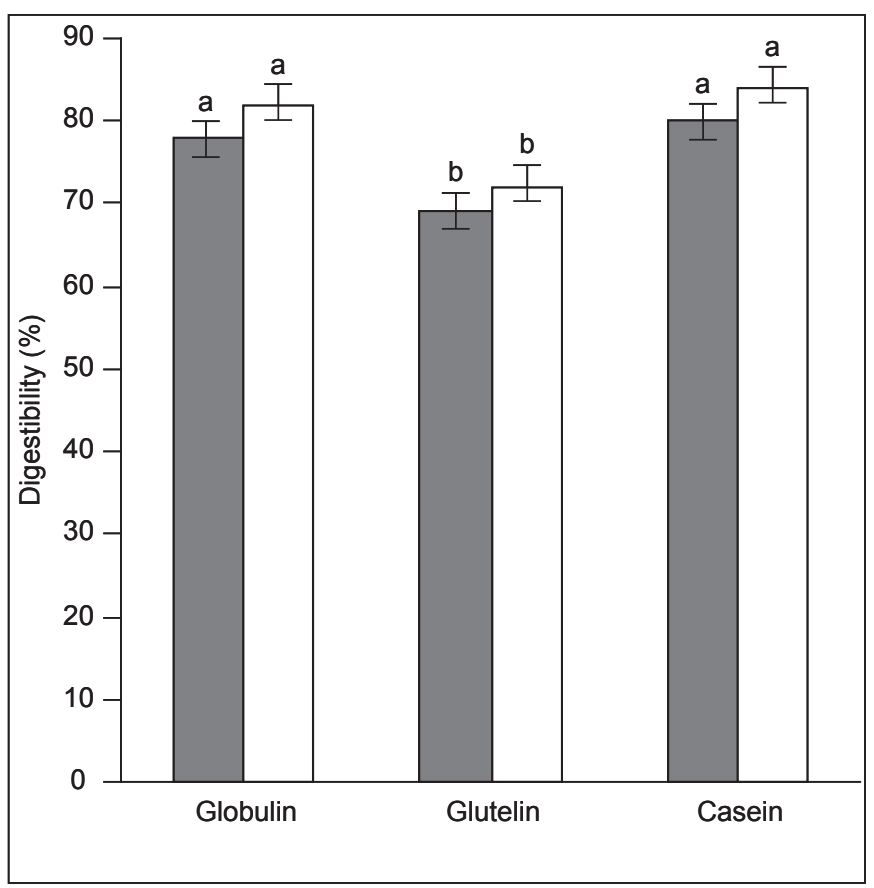

FIGURE 2 - In vitro digestibility of globulins and glutelins of bocaiúva, Acrocomia aculeata (Jacq.) Lodd., compared to a casein standard (mean $\pm \mathrm{SD}, \mathrm{n}=3$ ). Dark columns are unboiled samples; white columns are boiled samples. Repeated letters mean that no significant differences were found among treatments, according to Student's $t$ test $(\mathrm{p}<0.05)$.

\section{7 - Mineral contents}

The mineral contents shown in Table 5 are high when compared to the values obtained for other palmtree fruits of Mato Grosso do Sul [13]. Bocaiuva kernels are richer in manganese, copper and zinc (respectively, 24.3, 11.1 and $30.9 \mu \mathrm{g} / \mathrm{g}$ ) than other native fruits of the region; only kernels of piqui (Caryocar brasiliense Camb., a native tree of the cerrado) are described in the literature as richer in zinc and copper (respectively, 53.6 and $15.9 \mu \mathrm{g} / \mathrm{g}$ ) than the bocaiuva kernels [13].
TABLE 5 - Mineral content of kernels of bocaiuva, Acrocomia aculeata (Jacq.) Lodd., expressed in a wet weight basis.

\begin{tabular}{lc}
\hline \multicolumn{1}{c}{ Mineral } & $\mathbf{~ g g / 1 0 0 ~} \mathbf{g}$ \\
\hline Calcium & 94.3 \\
Magnesium & 207.0 \\
Phosphorus & 537.5 \\
Potassium & 377.2 \\
\hline & $\mu \mathrm{g} / \mathrm{g}$ \\
\hline Sodium & 21.41 \\
Iron & 32.91 \\
Manganese & 24.33 \\
Zinc & 30.93 \\
Copper & 11.13 \\
\hline
\end{tabular}

Values are the average of two repetitions.

\section{4 - DISCUSSION}

Separation and isolation based on solubility is a convenient system to begin the characterization of seed storage proteins from species that have not been studied yet [9].

In the present investigation, it was found that the defatted kernel flour of bocaiuva is a rich source of oil and protein. The kernel protein fraction is mostly composed of globulins (soluble in dilute saline solution) and glutelins (soluble in dilute acids or alkalis). Isolation of seed proteins has revealed that many plants (including Leguminosae) contain globulins as the main storage protein (50-75\% of total seed protein) $[5,7,23,31]$. Studies regarding the degradation of legume proteins, particularly globulins, have demonstrated that cooking and fermentation separates this protein fraction from antinutritional factors, such as proteinase inhibitors and lectins, which is a feature that makes globulin suitable for studies concerning the nutritional value of proteins [5, 7].

The agglutinating activity has been attributed to lectin (a hemagglutinating glycoprotein). In this study, the amount of it used in the agglutination assay was very high, indicating that bocaiúva globulin and glutelin fractions have very low lectin contents, in contrast with various plant seeds from which lectin has been isolated [7, 20, 29, 33].

As shown in Figure 2, a good level of in vitro digestibility was found for native and heated bocaiuva kernel globulins, as compared to the casein standard. However, the glutelin sample evaluated was less easily digested by proteases than casein, both under boiling and non-boiling conditions. The digestibility of bocaiuva globulin was similar to that of karkade flour (82.14\%) [1]. Results for bocaiuva differed from those obtained elsewhere for proteins from legume seeds, such as soy, algaroba (mesquite) and cowpea, which are resistant to hydrolysis by mammalian digestive enzymes, given the presence of protease inhibitors in the seeds [5, 24, 31].

The digestibility of the glutelin fraction of bocaiuva was also lower than that reported in the literature for the karkade protein [1] though similar to that of legume seed proteins, such as the chickpea and jojoba [23, 31]. 
The nonsignificant increase in the digestibility of bocaiuva kernel globulins and glutelins after boiling (Figure 2) revealed that neither protein fraction contains protease inhibitors associated with low protein digestibility of plant seeds [5, 33, 31].

When the mineral profiles shown in Table 5 are compared to those of selected edible seeds, bocaiuva kernels are found to be richer in calcium $(94.3 \mathrm{mg} / 100 \mathrm{~g})$, phosphorus (537.5 mg/100 g) and manganese $(24.3 \mu \mathrm{g} / \mathrm{g})$ than cashew nuts or fresh coconut [25]. The values found for minerals in the samples investigated, however, were below the recommended dietary allowances for adults [22].

The nutritional value of dietary proteins is determined by the profile and quantity of the essential amino acids they contain. The presence of one or more essential amino acids in adequate amounts increases the nutritional value of a protein. The amino acid profile (Table 3 ) shows that bocaiuva kernel protein fractions are potentially good sources of some of the essential amino acids as they are rich in methionine + cisteyne, valine and leucine. Threonine and lysine are the most limiting amino acids, respectively, from the two main protein fractions of bocaiuva kernel, globulin (amino acid score of the $47.1 \%$ ) and glutelin (amino acid score of the $49.5 \%$ ), in terms of the theoretical profiles for children in the age range of 2 to 5 years old. Methionine is an amino acid found at high concentrations in the proteins of other Brazilian fruits, such as castanha do Pará [27] and anajá [3] with values of $7.61 \%$ and $2.62 \%$ of the total protein content, respectively. The glutelin fraction of bocaiuva kernels have high nutritional values of methionine $13.3 \%$ of the glutelin fraction), if compared to the FAO's reference standards [8]. Plant storage proteins are generally rich in proline, asparagine, glutamine and arginine [7]. In bocaiuva kernel protein fractions, the predominant amino acids, in relation to the total found, were glutamine and arginine. In the globulin fraction (the main protein fraction of bocaiuva), the arginine and glutamine contents were found to be compatible with those determined by AMAYA-FARFÁN et al. [3] for another species of the same genus, A. sclerocarpa Mart. ( $13.86 \%$ and $19.79 \%$, respectively). In comparison to fruit from the cerrado, the jatobá-do-cerrado (Hymenaea stigonocarpa Mart.) seed showed that protein was deficient in sulphur amino acids and threonine and rich in other essential amino acids [21].

\section{5 - CONCLUSIONS}

Bocaiuva kernels are a valuable source of total proteins and lipids, and in contrast with legume seeds, do not contain protease inhibitors - a nutritional advantage in terms of digestibility. The kernels, however, are limiting in some essential amino acids such as threonine and lysine (the main limiting amino acids), a feature that suggests the need for additional studies to provide a better understanding of the in vivo protein digestibility and biological value of bocaiuva kernels. As for the mineral analysis, the samples analyzed showed lower values than those recommended as dietary allowances for adults.

\section{6 - REFERENCES}

[1] ABU-TAR BOUSH, H. M.; AHMED, S. A. B. Studies on karkade (Hibiscus sbadariffa): protease inhibitor, phytate, in vitro protein digestibility and gossypol content. Food Chemistry, v. 56, n. 1, p. 15-19, 1996.

[2] ALMEIDA, S. P. Cerrado-aproveitamento alimentar. Planaltina: EMBRAPA-CPAC, 1998. 188 p.

[3] AMAYA-FARFÁN, J.; RODRIGUEZ-AMAYA, D. B.; NOLETO CRUZ, P.; MARQUES, E. P. Fatty acid and aminoacid composition of some indigenous fruits of northeastern Brazil. Ciência e Tecnologia de Alimentos, v. 6, n. 1, p. 86-92, 1986.

[4] AOAC. Official methods of analysis, $16^{\text {th }}$ ed. Washington DC, USA: Association of Official Analytical Chemists, 1995. 109 p.

[5] ARAUJO, A. H.; CARDOSO, P. C. B.; PEREIRA, R. A.; LIMA, L. M.; OLIVEIRA, A. S.; MIRANDA, M. R. A.; XAVIER-FIILHO, J. SALLES, M. P. In vitro digestibility of globulins from cowpea (Vigna unguiculata) and xerophitic algaroba (Prosopis juliflora) seeds by mammalian digestive proteinases: a comparative study. Food Chemistry, v. 78, p. 143-147, 2002.

[6] BRADFORD, M. M. A rapid and sensitive method for the quantification of microgram quantities of protein using the principle of protein-dye binding. Analytical Biochemistry, v. 72, p. 248-254, 1976.

[7] DERBYSHIRE, E.; WRIGHT, D. J.; BOUTER, D. Legumin and vicilin storage proteins of legume seeds. Phytochemistry, v. 15, p. 3-24, 1976.

[8] FAO/WHO. Protein quality evaluation. Rome, Italy: Food and Agricultural Organization of the United Nations, 1991.

[9] FONSECA, P. A.; FERREIRA, R. B.; TEIXEIRA, A. R. Seed proteins from Quercus suber. Journal of Agricultural and Food Chemistry, v. 45, p. 3443-3447, 1997.

[10] FREIRE, M. G. M.; GOMES, V. M.; CORSINI, R. E.; MACEDO, M. L. R. Isolation and partial characterization of a novel lectin from Talisia esculenta seeds that interferes with fungal growth. Plant Physyology and Biochemistry, v. 40, p. 61-68, 2002.

[11] HENLEY, E. C.; KUSTER, J. M. Protein quality evaluation by protein digestibility - corrected amino acid scoring. Food Technology, v. 48, p. 74-77, 1994.

[12] HENRIKSON, R. L.; MEREDITH, S. C. Amino acid analysis by reverse phase high performance liquid chromatography: precolumn derivatization with phenylisothiocyanate. Analytical Biochemistry, v. 36, p. 65-71, 1984.

[13] HIANE, P. A.; RAMOS, M. I. L.; RAMOS FILHO, M. M.; BARROCAS, G. E. G. Teores de minerais de alguns frutos do Estado de Mato Grosso do Sul. Boletim do Centro de Pesquisa e Processamento de Alimentos, v. 10, n. 2, p. 135-150, 1992a.

[14] HIANE, P. A.; RAMOS, M. I. L.; RAMOS FILHO, M. M.; PEREIRA, J. G. Composição centesimal e perfil de ácidos graxos de alguns frutos nativos do Estado de Mato Grosso do Sul. Boletim do Centro de Pesquisa e Processamento de Alimentos, v. 10, n. 1, p. 35-42, $1992 b$ 
[15] HSU, H. W.; VAVAK, D. L.; SATTERLEE, L. D.; MILLER, G. A. A multienzyme technique for estimating protein digestibility. Journal of Food Science, v. 42, p. 1269-1273, 1977.

[16] INSTITUTO ADOLFO LUTZ. Normas analíticas do Instituto Adolfo Lutz. $3^{\text {rd }}$ ed. São Paulo, 1985. 533 p.

[17] LAEMMLI, U. K. Cleavage of structural proteins during the assembly of the head of bacteriophage T4. Nature, v. 227, p. $680-685,1970$.

[18] LIENER, I. E. Implications of antinutritional components in soybean foods. Critical Review of Food Science and Nutrition, v. 34, p. 31-67, 1994.

[19] MACEDO, M. L. R.; DAMICO, D. C. S. Effects of protein fractions from Zea mays L. on development and survival of mexican bean weevil Zabrotes subfasciatus (Boh.). Insect Science and Its Application. v. 20, p. 135-139, 2000 .

[20] MACEDO, M. L. R.; FREIRE, M. G. M.; CABRINI, E. C.; TOYAMA, M. H.; NOVELLO, J. C.; MARANGONI, S.; MATOS, D. G. G. A trypsin inhibitor from Peltophorum dubium seeds active against pest proteases and its effects on the survival of Anagasta kuehniella (Lepidoptera: Pyralidae). Biochimica et Biophysica Acta, v. 1621, p. 170-182, 2003.

[21] MATUDA, T. G.; MARIA NETTO, F. Caracterização química parcial da semente de jatobá-do-cerrado (Hymenaea stigonocarpa Mart.). Ciência e Tecnologia de Alimentos, v. 25, n. 2, p. 353-357, 2005.

[22] NATIONAL RESEARCH COUNCIL. Recommended dietary allowances, $10^{\text {th }}$ ed. Washington, D. C.: National Academy of Sciences, 1989.

[23] NEVES, V. A.; SILVA, M. A.; LOUREnÇO, E. J. Caracterização e hidrólise da globulina principal de grão de bico (Cicer arietinum L.), var. IAC - Marrocos. Ciência e Tecnologia de Alimentos, v. 24, n. 1, p. 139-145, 2004.

[24] OSHODI, A. A.; IPINMOROTI, K. O.; ADEYEYE, E.I.; HALL, G.M. In vitro multienzyme digestibility of protein of six varieties of African yam bean flours. Journal of Science and Food Agricultural, v. 69, p. 373-377, 1995.

[25] PHILIPPI, S. T. Tabela de composição de alimentos: suporte para decisão nutricional. $2^{\text {nd }}$ ed. São Paulo: Coronário, 2002. 135 p.
[26] PIMENTEL GOMES, F. Curso de estatística experimental. $14^{\text {th }}$ ed. Piracicaba: F. Pimentel-Gomes Ed. 2000. $477 \mathrm{p}$

[27] RIBEIRO, M. A. A. Aproveitamento tecnológico de castanha-do-Brasil (Bertholletia excelsa): estudo da conservação. Dissertação (Mestrado). Piracicaba: Escola Superior de Agricultura "Luis de Queiroz"/USP], 1982. $88 \mathrm{p}$.

[28] SALINAS, Y. G.; GARCIA, R. Métodos químicos para el analisis de suelos acidos y plantas forrajeras. Cali: Centro Internacional de Agricultura Tropical, 1985. 83 p.

[29] SEENA, S.; SRIDHAR, K. R. Nutrient composition and biological evaluation of an unconventional legume, Canavalia cathartica of mangroves. International Journal of Food Science and Nutrition, v. 55, p. 615$625,2004$.

[30] SGARBIERI, V. C. Proteínas em alimentos protéicos: propriedades - degradações - modificações. São Paulo: Varela, 1996. 517 p.

[31] SHRESTHA, M. K.; PERI, I.; SMIRNOFF, P.; BIRK, Y.; GOLAN-GOLDHIRSH, A. Jojoba seed meal proteins associated with proteolytic and protease inhibitory activities. Journal of Agricultural and Food Chemistry, v. 50, p. 5670-5675, 2002.

[32] VAN SOEST, P. J.; WINE, R. H. Use of detergents in the analysis of fibrous food. IV. Determination of cell-wall constituents. Journal of Association of Analytical Chemistry, v. 50, p. 50-55, 1967.

[33] VASCONCELOS, I. M.; MAIA, A. A. B.; SIEBRA, E. A., OLIVEIRA, J. T. A.; CARVALHO, A. F. F. U.; MELO, V. M. M.; CARLINI, C. R.; CASTELAR, L. I. M. Nutritional study of two Brazilian soybean (Glycine max) cultivars differing in the contents of antinutritional and toxic proteins. Journal of Nutrition and Biochemistry, v. 12 , p. $55-62,2001$.

\section{7 - ACKNOWLEDGMENTS}

The authors wish to thank the FUNDECT (Fundação de Apoio ao Desenvolvimento do Ensino, Ciência e Tecnologia) of the Brazilian state of Mato Grosso do Sul, CNPq (Conselho Nacional de Desenvolvimento Científico e Tecnológico), PROPP/UFMS (Pró-Reitoria de Pesquisa e Pós-Graduação/ Universidade Federal de Mato Grosso do Sul) and FINEP/MCT (Financiamento de Estudos e Projetos/Ministério da Ciência e Tecnologia) for the financial support of this research. 